\section{Sobre Copas do Mundo...}

\section{About World Cups...}

O ano de 2015 ficará marcado na história do futebol mundial como o ano em que a até então intocável cúpula político-administrativa da FIFA, finalmente, começou a ser imputada de seus crimes de lavagem de dinheiro, sonegação fiscal e corrupção.

Mesmo que as investigações ainda em curso indiquem que boa parte dessas infrações teria sido praticada durante os preparativos das Copas do Mundo de futebol, muito provavelmente poucos duvidam de que, ao longo dos próximos anos, milhões de pessoas ao redor do mundo estarão conectadas de alguma maneira às competições organizadas pela principal entidade supranacional, como estiveram ligadas à Rússia, país que sediou os jogos da XXI edição, em 2018.
Em pleno clima de descrença e festividade que paira sobre o futebol mundial, a revista FuLiA / UFMG, por meio do Dossiê Sobre Copas Do Mundo..., apresenta pesquisas que, independentemente de suas abordagens teóricas, metodológicas ou contextuais, se relacionam com o maior evento esportivo internacional, tanto a partir do viés historiográfico, memorialista e sociológico, como do viés artístico e cultural.

A seção Dossiê abre com o artigo "A cultura das figurinhas: as configurações de linguagens do colecionismo no álbum da Copa do Mundo FIFA 2018", de Anderson Gurgel Campos e Helena Maria Afonso Jacob, que analisam o fenômeno do colecionismo no álbum da Copa do Mundo da Rússia 2018, sob o ponto de vista dos significados tanto deste objeto como das relações que os fãs desenvolvem com as figurinhas e com o álbum. 0 objetivo é contribuir para o melhor entendimento da Copa do Mundo como texto da cultura e 
para a reflexão sobre as práticas realizadas nesse evento e seus impactos no público.

Por sua vez, Carlos Rodrigues e Emanuel Leite Jr. contribuem para o presente dossiê com o artigo "A geopolítica do futebol em transformação: o caso chinês", no qual analisam de que forma o futebol chinês tem contribuído, por meio de estratégias das autoridades da China, para mudar a geopolítica do futebol. Para tanto, em 2016, foi lançado o "Plano de desenvolvimento do futebol a médio e longo prazo (2016-2050)". Dentre os objetivos, está o de sediar uma Copa.

Em “A importância dos imigrantes e descendentes na seleção francesa ao longo das Copas do Mundo", Guilherme Silva Pires de Freitas apresenta um histórico realçando a importância dos imigrantes. 0 artigo mostra ainda o peso que o futebol tem para sociedade francesa, que através da modalidade consegue discutir e debater delicados assuntos de interesse nacional.
Em “Análise da composição de títulos e manchetes do diário Olé durante a cobertura das Copas do Mundo de 2014 e 2018", Mauro César Silveira e Matheus Simões Mello estudam o diário argentino Olé durante a cobertura das Copas do Mundo de 2014 e 2018. A fundamentação teórica traz obras que refletem acerca da linguagem jornalística esportiva, a estrutura de chamadas de textos no jornalismo esportivo e os elos entre emoção e a editoria de esportes.

Outra contribuição para o presente dossiê é o artigo de Fernando Vannier Borges, "Ao vivo direto da Rússia: a Copa do Mundo formatada para televisão", no qual é demonstrado como a Copa do Mundo é capaz de gerar tanta atenção da mídia. Através da análise da versão de 2018 do Manual de Produção para TV da FIFA, o texto mostra de que maneira essa instituição contribui para a transformação da Copa do Mundo em um produto de televisão. 
Para as suas reflexões em "Arte e tragédia: representações sobre a seleção brasileira de 1982 em livros do século XXI", Diano Albernaz Massarani procura compreender a Tragédia do Sarriá - jogo entre Itália 3x2 Brasil na Copa da Espanha - como um dos eventos mais rememorados e intrigantes do futebol brasileiro. 0 autor analisa a construção de representações sobre o estilo de jogo da seleção brasileira de 1982, em livros publicados neste século. Décadas após a Tragédia do Sarriá, a seleção ainda é representada como a última que praticou o futebol-arte, estilo de jogo tido como "genuinamente" do Brasil.

O dossiê conta também com o artigo "Copa do Mundo 2014: uma abordagem pedagógica sobre o seu legado", no qual Amarildo da Silva Araujo nos apresenta como a realização da Copa do Mundo no Brasil trouxe mudanças nas cidades-sedes e produziu impactos na economia, na política e no espaço urbano. Esse estudo analisa a opinião dos professores de uma escola pública de Belo Horizonte/MG sobre o legado do megaevento.

Por sua vez, o artigo "Nem complexo de vira-latas, nem herói genial: o caso peculiar da imprensa de Montes Claros frente às máximas de Nelson Rodrigues nas Copas de 1958 e 1962", de Luciano Pereira da Silva e Rogério Othon Teixeira Alves, discute nuanças que pairam sobre o tema Copa do Mundo e o próprio futebol, especificamente no período que circundou a Copa de 1958, tomando por base a imprensa do Rio de Janeiro e a cidade de Montes Claros/MG. Mesmo que o futebol já detivesse significativa importância, não se nota no jornal mineiro crônicas análogas às feitas ao estilo de Nelson Rodrigues, supostamente refletindo o brasileiro através do futebol.

Por fim, José Carlos Marques e Nathaly Barbieri Marcondes César, em "O futebol-arte brasileiro: uma tradição continuamente reinventada e contestada", verificam como 
a visão fundada por Gilberto Freyre (1938) a respeito do futebol-arte ainda mantém força, renovada a cada Copa do Mundo, especialmente por emissoras televisivas, ao passo que outros discursos, sobretudo o acadêmico, procuram desmistificar essa visão.

Na seção Entrevista, "O Centro de Memória do Vasco da Gama”, Elcio Loureiro Cornelsen, Gustavo Cerqueira Guimarães e Marcus Vinícius Costa Lage conversam em conjunto com o vice-presidente de relações especializadas do Vasco da Gama, João Ernesto da Costa Ferreira, e com o diretor de acervo do Centro de Memória do clube, doutor em História, Adílio Jorge Marques.

Na seção Paralelas, os historiadores Elizabeth da Cunha Süssekind e Marcus Vinícius Macri Rodrigues constroem o artigo "O tempo livre do trabalhador sob controle: comparação entre o Serviço de Recreação Operária e a Comunidade Nacional-Socialista Força pela Alegria" com o objetivo de analisar, sob uma perspectiva comparativa, o primeiro ano de atividade do S. R. O., criado no final do ano de 1943, durante a ditadura de Getúlio Vargas, como órgão destinado a promover o lazer e a cultura do operário sindicalizado. Para tanto, são utilizadas matérias publicadas em periódicos, especialmente no jornal $A$ Noite. Essa investigação é contraposta ao tempo livre do trabalhador na Alemanha, antes e durante o regime nazista. A seção Poética, dedicada às múltiplas possibilidades das abordagens artísticas do futebol e do mundo dos esportes, reúne nesta edição a série de charges do artista belo-horizontino Eduardo dos Reis Evangelista, o Duke, publicada originalmente no caderno especial "Copa 2018", do jornal O Tempo, de Belo Horizonte/MG, no período de 14 de junho a 16 de julho de 2018, ao longo da Copa do Mundo da Rússia. Esse trabalho reunido, agora, é intitulado "Duke na Copa de 2018", que evidencia uma vez mais a capacidade do artista de 
transformar em humor aspectos que relacionam o futebol, a política e os nossos assuntos do dia a dia.

Por fim, terminamos a preparação da presente edição da revista FuLiA / UFMG após a Copa do Mundo realizada na Rússia, torneio também fortemente marcado por dimensões políticas, o que nos confere a certeza de que o futebol será ainda por muitos anos objeto de investigação de pesquisadores pelo mundo.

Belo Horizonte, 11 de dezembro de 2018.

Gustavo Cerqueira Guimarães Estudos Literários, UFMG

Marcus Vinícius Costa Lage História, UFMG

Thiago Carlos Costa Estudos do Lazer, UFMG

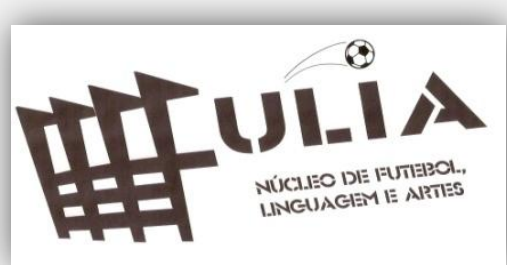

